\title{
PROFIL METAKOGNISI MAHASISWA PEREMPUAN DALAM MENYELESAIKAN MASALAH BANGUN DATAR DITINJAU DARI GAYA KOGNITIF REFLEKTIF DAN IMPULSIF
}

\author{
Sugiyanti ${ }^{1)}$, Rizky Esti Utami ${ }^{2}$, Kristi Indriana ${ }^{3)}$ \\ ${ }^{1}$ Fakultas Pendidikan MIPA dan Teknologi Informasi, Universitas PGRI Semarang \\ email: sugiyanti@upgris.ac.id \\ ${ }^{2}$ Fakultas Pendidikan MIPA dan Teknologi Informasi, Universitas PGRI Semarang \\ email: rizkyesti@upgris.ac.id \\ ${ }^{3}$ Fakultas Pendidikan MIPA dan Teknologi Informasi, Universitas PGRI Semarang \\ email: kristiindriana@gmail.com
}

\begin{abstract}
This qualitative study described the metacognition of female students with reflective and impulsive cognitive style in solving the problems of plane. The subjects of the study were female students of the fourth semester in Universitas PGRI Semarang period 2016/2017 whom was given the problems of plane. Data collection applies think aloud method. The analysis of data focused on students' metacognitive ability in three steps, i.e. planning, monitoring, and evaluating.This research showed that: 1) metacognitive ability of female mathematics students with impulsive cognitive style in solving the problem was not able to realize the thinking process, causing student has not been able to answer all the given problems with the correct results; and 2) metacognitive ability of female mathematics students with reflective cognitive style in solving the problem was able to realize the thinking process well in the planning, monitoring and evaluating stages, causing subject is able to answer all the given problems with the correct result.
\end{abstract}

Keywords: Profile; Metacognition; Reflective; Impulsive

\begin{abstract}
Abstrak: Penelitian kualitatif ini mendeskripsikan metakognisi mahasiswa perempuan dengan gaya kognitif reflektif dan impulsif dalam menyelesaikan masalah bangun datar. Subjek penelitian adalah mahasiswa perempuan semester IV Universitas PGRI Semarang periode 2016/2017 yang diberikan soal pemecahan masalah bangun datar. Teknik pengumpulan data menggunakan metode Think Aloud Method. Analisis data difokuskan pada kemampuan metakognitif mahasiswa dalam tiga tahap yaitu perencanaan, pemantauan, dan pengevaluasian. Hasil penelitian menunjukkan bahwa: 1) kemampuan metakognitif mahasiswa matematika berjenis kelamin perempuan dengan gaya kognitif impulsif dalam pemecahan masalah belum mampu menyadari proses berpikirnya dengan baik, menyebabkan subjek belum mampu menjawab semua permasalahan yang diberikan dengan hasil akhir yang benar; dan 2) kemampuan metakognitif mahasiswa matematika berjenis kelamin perempuan dengan gaya kognitif reflektif dalam pemecahan masalah mampu menyadari proses berpikirnya dengan baik pada tiga tahap metakognitif menyebabkan subjek mampu menjawab semua permasalahan yang diberikan dengan hasil akhir yang benar.
\end{abstract}

Kata kunci: Profil; Metakognisi; Reflektif; Impulsif

\section{PENDAHULUAN}

Untuk menyelesaikan soal, seorang mahasiswa perlu mengelola pikirannya dengan baik dengan memanfaatkan pengetahuan yang sudah dimiliki, mengontrol dan merefleksi proses dari hasil berpikirnya sendiri, karena apa yang dipikirkan dapat membantunya dalam menyelesaikan soal. Kesadaran akan proses berpikirnya ini yang disebut metakognisi. 
(Flavell,1979; De Soete, 2003; dan Panoura, 2004) menjelaskan metakognisi terdiri dari pengetahuan metakognitif dan pengalaman atau pengarahan metakognitif. Pengetahuan metakognitif merupakan interaksi antara tiga variabel yakni variabel individu (person variabel), variabel strategi (strategy variabel), dan variabel tugas (task variabel).

Metakognisi mahasiswa dapat menjadi tolak ukur kemampuan mahasiswa dalam menyelesaikan soal matematika. Kemampuan menyelesaikan soal matematika dengan berbagai macam cara yang berbeda dipengaruhi oleh gaya kognitif, misalnya gaya kognitif reflektif dan impulsif. Menurut (Warli,2010), anak yang menggunakan waktu yang lama dalam menjawab masalah, tetapi cermat atau teliti sehingga jawaban yang diberikan cenderung benar, disebut anak yang bergaya kognitif reflektif. Sedangkan anak yang menggunakan waktu yang singkat dalam memecahkan masalah, tetapi kurang cermat sehingga jawaban cenderung salah, disebut anak yang bergaya kognitif impulsif.

Terkait dengan kesalahan dalam penyelesaian masalah, (Muhtarom, 2013) menyatakan bahwa banyak sekali kesalahan yang dibuat oleh mahasiswa dalam menyelesaikan masalah bangun datar. Secara ringkas kesalahan tersebut meliputi: 1) kesalahan dalam memahami konsep karena definisi yang diterima mahasiswa tidak terkait dengan pemahaman fakta yang dimilikinya, 2) kesalahan dalam mendefinisikan suatu bangun terjadi karena mahasiswa hanya memberikan ungkapan verbal (definisi) suatu bangun tidak mendasarkan pada konsep yang telah dimiliki. 3) kesalahan dalam menemukan rumus terjadi karena tidak tahu bahwa rumus adalah sesuatu yang perlu diketahui buktinya.
Lebih lanjut, menurut (Flavell ,1979) kemampuan mahasiswa untuk memantau berbagai macam aktivitas kognisinya dilakukan melalui aksi dan interaksi antara empat komponen, yaitu pengetahuan (metacognitive knowledge), pengalaman metakognitif (metacognitive experiences), tujuan kognitif (cognitive goals), dan strategi kognitif (cognitive stategies). Pemanfaatan aktivitas metakognitif turut mempengaruhi keberhasilan mahasiswa dalam menyelesaikan soal (Wong, 1992; Panoura, 2005; Gama, 2004). Pendapat tersebut memaparkan bahwa penyelesaian soal matematika merupakan suatu proses yang kompleks yang memerlukan visualisasi, imajinasi, manipulasi, analisis, abstraksi, dan penyatuan ide. Dalam proses penyelesaian soal matematika terjadi interaksi antara aktivitas kognitif dan metakognitif. Aktivitas kognitif terbatas pada bagaimana informasi diproses untuk mencapai tujuan, sedangkan aktivitas metakognitif penekanannya pada kesadaran mahasiswa terhadap apa yang dilakukannya. Penyelesaian soal akan diawali dengan bagaimana mahasiswa mengenali soal tersebut (misalnya dengan membangun representasi mental dari soal yang dibaca), kemudian memutuskan bagaimana menyelesaikan soal itu sampai dengan bagaimana mengevaluasi hasil yang dibuatnya.

(Polya, 1973) mendefinisikan pemecahan masalah sebagai usaha mencari jalan keluar dari suatu kesulitan, mencapai suatu tujuan yang tidak dengan segera dapat dicapai. (Bergenson,2000) menyatakan bahwa masalah matematika dalam problem solving yaitu masalah harus sistematis, konteks masalah adalah objek nyata atau simulasi objek nyata, situasi masalah menarik bagi pebelajar karena sifat material masalah, masalah harus memberikan kesempatan kepada pebelajar untuk 
melakukan transformasi atau modifikasi, masalah harus memberikan kesempatan tingkat pemecahan yang berbeda, dan situasi apapun yang dipilih sebagai sarana khusus bagi suatu masalah memungkinkan menciptakan situasi lain yang memiliki struktur matematis yang sama. Penyelesaian masalah merupakan perwujudan dari suatu aktifitas mental yang terdiri dari bermacammacam keterampilan dan tindakan kognitif (Kirkley, 2003) yang dimaksudkan untuk mendapatkan solusi yang benar dari masalah. Khusus dalam penyelesaian masalah matematika, salah satu yang banyak dirujuk adalah pentahapan oleh (Polya,1973), yang mengemukakan empat tahapan penting yang perlu dilakukan yaitu: memahami masalah (understanding the problem), membuat rencana (devising a plan), melaksanakan rencana (carrying out the plan), dan mengecek kembali (looking back).

Perbedaan gender memungkinkan adanya pengaruh dalam pencapaian hasil belajar (Geary, Saults, Liu, 2000; Goodchild \& Granholm, 2007). Perempuan dan laki-laki memiliki preferensi yang berbeda dalam penggunaan strategi pemecahan masalah (Zhu, 2007). Lebih lanjut (Geary, Saults, dan Liu, 2000) percaya bahwa pengaruh faktor gender dalam matematika karena adanya perbedaan biologis dalam otak anak lakilaki dan perempuan, dimana secara umum perempuan lebih unggul dalam bidang bahasa dan menulis, sedangkan laki-laki lebih unggul dalam bidang matematika karena kemampuan keruangan yang lebih baik.

Berdasarkan uraian terkait peran aktivitas metakognitif dalam pemecahan masalah (Wong, 1992; Panoura, 2005; Gama, 2004), pemecahan masalah dalam pembelajaran matematika (Polya, 1967; Kirkley, 2003) khususnya dalam bangun datar (Muhtarom, 2013) dan preferensi strategi pemecahan masalah berdasarkan gender (Zhu, 2007). Penelitian ini bertujuan mengetahui profil aktivitas metakognitif mahasiswa perempuan dalam menyelesaikan masalah matematika ditinjau dari gaya kognitif. Jika dilihat dari sisi kuantitas, mahasiswa perempuan di program studi Pendidikan Matematika lebih banyak daripada mahasiswa laki-laki. Hal ini menjadi alasan mengapa penelitian ini memilih subyek mahasiswa perempuan.

\section{METODE PENELITIAN}

Mahasiswa perempuan semester IV Universitas PGRI Semarang periode 2016/2017 diberikan tes uraian untuk diselesaikan dalam waktu 30 menit. Tabel 2 menunjukkan indikator gaya kognitif subjek dalam menyelesaikan tes. Penentuan gaya kognitif reflektif dan impulsif dapat dilihat dari banyaknya jawaban siswa yang benar atau salah dalam waktu yang lambat dan banyaknya jawaban siswa yang benar atau salah dalam waktu yang cepat.

Berdasarkan hasil tes dan kemampuan mengkomunikasikan gagasan baik secara lisan maupun tulisan (karena hal ini akan menentukan kelancaran proses pengumpulan data selanjutnya yaitu wawancara), ditentukan dua subjek yang memiliki gaya kognitif reflektif (S-DA) dan impulsif (S-DU)

Tabel 1. Kategori Gaya Kognitif Subjek

\begin{tabular}{c|c|c}
\hline $\begin{array}{l}\text { Waktu } \\
\text { Menjawab }\end{array}$ & $\begin{array}{l}\text { Jawaban } \\
\text { Salah }\end{array}$ & $\begin{array}{l}\text { Gaya } \\
\text { Kognitif }\end{array}$ \\
\hline$>15,5$ menit & $<3$ soal & Reflektif \\
\hline$\leq 15,5$ menit & $\geq 3$ soal & Impulsif \\
\hline \multicolumn{2}{c}{ Subjek yang terpilih diberi soal } \\
tentang bangun datar kemudian
\end{tabular}
diwawancarai untuk memverifikasi data hasil tes penyelesaian soal dan mendapat informasi lebih jelas tentang metakognisi subjek dalam menyelesaikan soal bangun datar yang tidak bisa diungkapkan dengan tulisan. Selanjutnya dilakukan tes tertulis lagi yang bertujuan untuk memperoleh data 
kemampuan metakognitif subjek dalam menyelesaikan permasalahan matematika. Tes tertulis ini dilaksanakan pada waktu dan tempat yang berbeda terhadap setiap subjek, untuk menjamin keabsahan data penelitian yaitu triangulasi waktu. Pengumpulan data berikutnya adalah pengecekan jawaban subjek dengan wawancara. Wawancara bertujuan untuk pengecekan jawaban subjek terkait dengan kemampuan metakognitif dalam penyelesaian soal bangun datar.

Aktivitas metakognisi yang dilakukan mahasiswa dalam menyelesaikan soal dapat memperlihatkan keterampilan metakognisi. Aktivitas yang terlihat dari tes dan wawancara disajikan dalam Tabel 2.

Tabel 2. Indikator Aktivitas Metakognisi Mahasiswa

(Istarini, 2010)

\begin{tabular}{|c|c|c|}
\hline Tahap & \multicolumn{2}{|c|}{ Aktivitas-aktivitas yang dapat dilihat dari } \\
\hline Metakognisi & Tes Tulis & Tes wawancara \\
\hline $\begin{array}{l}\text { Perencanaan } \\
\text { (planning) }\end{array}$ & $\begin{array}{l}\text { - Adanya penulisan rencana } \\
\text { penyelesaian terlihat dari model } \\
\text { matematika yang dibuat mahasiswa } \\
\text { - Apa yang diketahui dan ditanyakan } \\
\text { dari masalah ditulis dengan benar }\end{array}$ & $\begin{array}{l}\text { - Adanya penjelasan yang disampaikan } \\
\text { mahasiswa tentang rencana strategi yang } \\
\text { digunakan } \\
\text { - Kesadaran akan kemampuannya sendiri } \\
\text { terlihat dari apakah mahasiswa } \\
\text { menyadari apa yang harus dilakukan } \\
\text { ketika ia tidak memahami soal } \\
\text { - Adanya penjelasan mahasiswa tentang } \\
\text { kesannya atau apa yang ada di dalam } \\
\text { pikirannya setelah membaca soal. }\end{array}$ \\
\hline $\begin{array}{l}\text { Pemantauan } \\
\text { (monitoring) }\end{array}$ & $\begin{array}{lr}\text { - } & \text { Adanya jawaban dari mahasiswa } \\
\text { mengenai strategi-strategi yang } \\
\text { digunakannya } & \text { dalam } \\
\text { menyelesaikan soal } & \\
\text { - } & \text { Membandingkan } \\
& \text { pekerjaannya dengan informasi } \\
& \text { yang diketahui }\end{array}$ & $\begin{array}{l}\text { - Adanya penjelasan yang disampaikan } \\
\text { mahasiswa tentang strategi yang } \\
\text { digunakan dalam menyelesaikan soal } \\
\text { dan alasan mahasiswa yang memberi } \\
\text { tanda garis bawah pada angka-angka } \\
\text { atau kata-kata yang dianggap penting } \\
\text { - Mahasiswa menyadari kesalahan yang } \\
\text { dibuatnya, seperti kesalahan dalam } \\
\text { menghitung } \\
\text { - Mampu memberikan argumen yang } \\
\text { mendukung pikirannya }\end{array}$ \\
\hline $\begin{array}{l}\text { Pengevaluasian } \\
\text { (evaluation) }\end{array}$ & $\begin{array}{l}\text { - Adanya penulisan “jadi” pada } \\
\text { jawaban mahasiswa } \\
\text { - Adanya perbaikan jawaban }\end{array}$ & $\begin{array}{l}\text { - Adanya penjelasan mahasiswa tentang } \\
\text { kegiatannya dalam memeriksa kembali } \\
\text { jawaban yang ditulisnya } \\
\text { - Adanya penjelasan tentang alasan } \\
\text { mahasiswa melakukan } \\
\text { penghapusan/penggantian jawaban } \\
\text { semula dengan jawaban akhir } \\
\text { - Mahasiswa meyakini hasil yang } \\
\text { diperolehnya adalah jawaban yang benar }\end{array}$ \\
\hline
\end{tabular}

\section{HASIL DAN PEMBAHASAN}

Analisis data pada penelitian ini difokuskan pada aktivitas metakognitif mahasiswa berdasarkan tahap-tahap metakognisi yaitu perencanaan (planning), pemantauan (monitoring), dan pengevaluasian (evaluation). 


\section{Metakognitif mahasiswa perempuan dengan gaya kognitif reflektif \\ Tahap perencanaan (planning)}

Subjek S-DA tidak mengalami kesalahan pada tahap perencanaan (planning). Hal ini terlihat pada jawaban subjek S-DA yang mampu menyusun rencana tindakannya dengan berusaha menyadari proses berpikirnya saat mengidentifikasi informasi dalam permasalahan, sehingga subjek tersebut mampu memaknai soal dengan baik. Hal tersebut dapat dilihat dengan adanya penulisan hal yang diketahui dan yang ditanyakan dari masalah ditulis dengan benar, serta adanya penulisan rencana penyelesaian terlihat dari model matematika yang dibuat mahasiswa yaitu belah ketupat. Subjek menuliskan hal yang diketahui yaitu jarak kota A ke kota B, ditengah kota $\mathrm{A}$ dan $\mathrm{B}$ ada kota $\mathrm{O}$, jarak $\mathrm{CD}, \mathrm{AB} \perp \mathrm{CD}$ serta rute yang ditempuh. Jawaban subjek dapat dilihat pada gambar berikut.

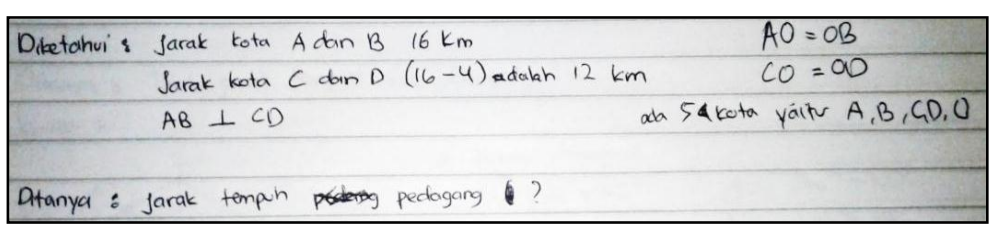

Gambar 1. Jawaban Subjek DA tahap Perencanaan
Tahap perencanaan subjek S-DA terhadap soal juga dijelaskan kembali pada saat wawancara dengan peneliti. Subjek memberikan penjelasan tentang rencana strategi yang digunakan, menyadari apa yang harus dilakukan ketika tidak memahami soal dan adanya penjelasan subjek tentang apa yang ada dipikirannya setelah membaca soal.

\section{Tahap pemantauan (monitoring)}

Subjek S-DA tidak mengalami kesulitan pada tahap pemantauan (monitoring). Terlihat pada jawaban subjek
S-DA mampu melaksanakan rencana termasuk memeriksa setiap langkah pemecahan, apakah langkah yang dilakukan sudah benar atau dapatkah dibuktikan bahwa langkah tersebut benar. Hal tersebut dapat dilihat dengan adanya penulisan mengenai strategi-strategi yang digunakan dalam menyelesaikan soal dan membandingkan hasil pekerjaannya dengan informasi yang diketahui serta pemeriksaan setiap langkah. Dalam pemeriksaan terhadap pekerjaannya, subjek menemukan adanya kesalahan.

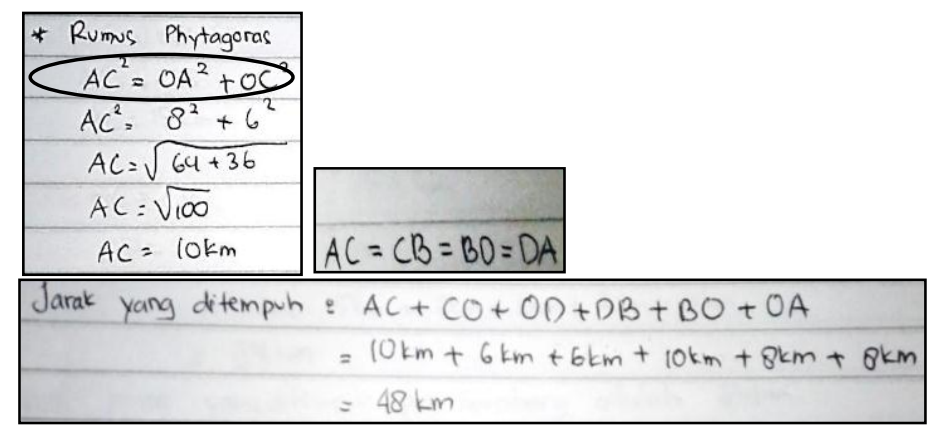

Gambar 2. Jawaban Subjek DA tahap Monitoring

Tahap pemantauan (monitoring) subjek S-DA terhadap soal juga dijelaskan kembali pada saat wawancara dengan peneliti. Subjek memberikan penjelasan 
tentang strategi yang digunakan dalam menyelesaikan soal dan mampu memberikan argument yang mendukung pikirannya. Subjek menyadari kesalahan yang dibuatnya yaitu pada rumus phytagoras subjek menuliskan $A C^{2}=O A^{2}+O C$ setelah itu diperbaiki menjadi $A C^{2}=O A^{2}+O C^{2}$. Subjek kemudian dapat menunjukkan bahwa setiap langkah tersebut benar dan meneliti perhitungan dengan benar.

\section{Tahap pengevaluasian (evaluation)}

Subjek S-DA tidak mengalami kesalahan pada tahap pengevaluasian (evaluation). Terlihat pada jawaban bahwa subjek S-DA menuliskan "jadi jarak yang ditempuh adalah $48 \mathrm{~km}$ " merujuk pada tujuan yang hendak dicapai dengan tepat, mengevaluasi hasil dari pelaksanaan suatu strategi berdasarkan kriteria efisien dan efektivitas.

\section{Jadi Jarak yang ditempuh deh pedagang tercebut adalah $48 \mathrm{~km}$}

Gambar 3. Jawaban Subjek DA tahap Evaluasi

Tahap pengevaluasian (evaluation) subjek S-DA terhadap soal juga dijelaskan kembali pada saat wawancara dengan peneliti. Subjek memberikan penjelasan tentang kegiatan dalam memeriksa kembali jawaban yang ditulisnya, adanya penjelasan tentang alasan subjek menggangti jawaban semula dengan jawaban akhir dan subjek meyakini hasil yang diperolehnya adalah jawaban yang benar.

\section{Metakognitif mahasiswa perempuan} dengan gaya kognitif impulsif

Tahap perencanaan (planning)

Subjek S-DU tidak mengalami kesalahan pada tahap perencanaan (planning). Hal ini bisa terlihat pada jawaban subjek S-DU yang mampu menyusun rencana tindakannya dengan berusaha menyadari proses berpikirnya saat mengidentifikasi informasi dalam permasalahan, sehingga subjek tersebut mampu memaknai soal dengan baik. Hal tersebut dapat dilihat dengan adanya penulisan hal yang diketahui dan hal yang ditanyakan dari masalah ditulis dengan benar, serta adanya penulisan rencana penyelesaian terlihat dari model matematika yang dibuat mahasiswa yaitu layang-layang. Hal yang diketahui oleh subjek yaitu pak bambang mengantar paket ke rumah $\mathrm{A}, \mathrm{B}, \mathrm{C}$, dan $\mathrm{D}$, jarak rumah $\mathrm{A}$ ke B $24 \mathrm{~km}$, tepat ditengah rumah A dab B terdapat kantor, misalkan kantor adalah $\mathrm{k}$, jarak rumah $\mathrm{C}$ ke kantor $9 \mathrm{~km}$, jarak rumah D ke kantor $16 \mathrm{~km}$ serta jalan lurus rumah A ke $\mathrm{B}$ tegak lurus dengan jalan rumah $\mathrm{C}$ ke D. Hal yang ditanyakan juga tepat yaitu total jarak tempuh Pak Bambang. Jawaban subjek dapat dilihat pada gambar.

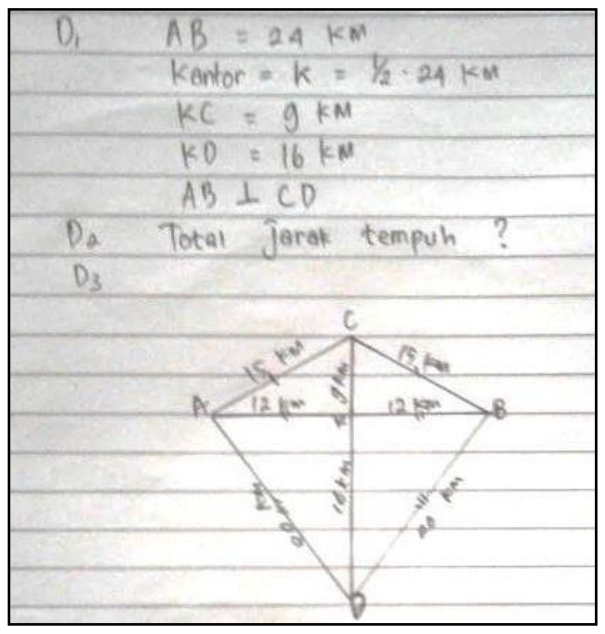

Gambar 4. Jawaban Subjek DU tahap Perencanaan

Tahap perencanaan subjek S-DU terhadap soal juga dijelaskan kembali pada 
saat wawancara dengan peneliti. Subjek memberikan penjelasan tentang rencana strategi yang digunakan, menyadari apa yang harus dilakukan ketika tidak memahami soal dan adanya penjelasan subjek tentang apa yang ada dipikirannya setelah membaca soal.

\section{Tahap pemantauan (monitoring)}

Subjek S-DU melakukan kesalahan pada tahap pemantauan (monitoring). Terlihat pada jawaban subjek S-DU yang mampu melaksanakan rencana termasuk memeriksa setiap langkah pemecahan, tetapi subjek tidak menyadari adanya kesalahan perhitungan. Hal tersebut dapat dilihat dengan adanya penulisan mengenai strategi-strategi yang digunakan dalam menyelesaikan soal dan membandingkan hasil pekerjaannya dengan informasi yang diketahui serta pemeriksaan setiap langkah. Pada penyelesaian ini subjek menuliskan bahwa hasil penjumlahannya adalah $85 \mathrm{~km}$ seharusnya $84 \mathrm{~km}$. Subjek S-DU juga melakukan kesalahan pada penulisan rumus Phytagoras, subjek menuliskan $A C^{2}=A k^{2}+k C$ dan $A D^{2}=A k^{2}+k D$ sehingga menyebabnya salahnya jawaban akhir. Jawaban subjek dapat dilihat pada gambar berikut.

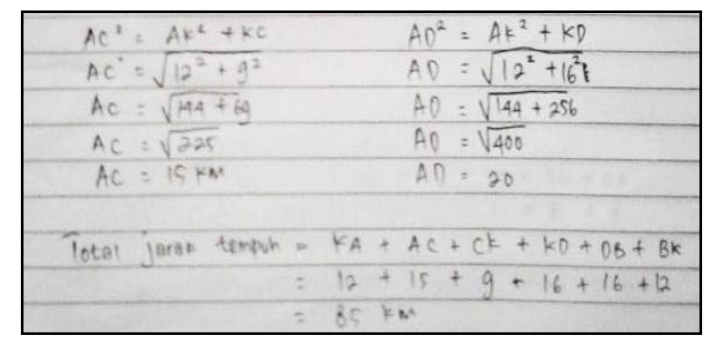

Gambar 5. Jawaban Subjek DU tahap

\section{Monitoring}

Tahap pemantauan (monitoring) subjek S-DU terhadap soal juga dijelaskan kembali pada saat wawancara dengan peneliti. Subjek memberikan penjelasan tentang strategi yang digunakan dalam menyelesaikan soal, tetapi tidak menyadari adanya kesalahan dan tetap meyakini bahwa jawabannya tepat.

\section{Tahap pengevaluasian (evaluation)}

Subjek S-DU melakukan kesalahan pada tahap pengevaluasian (evaluation). Terlihat pada jawaban subjek S-DU yang menuliskan "jadi total jarak ditempuh adalah $85 \mathrm{~km}$ " merujuk pada tujuan yang hendak dicapai dengan kurang tepat, tidak meneliti kembali kebenaran pekerjaannya, tidak mengenali adanya kesalahan dan tidak melakukan perbaikan pada kesalahan. Jawaban subjek dapat dilihat pada gambar berikut.

\section{Tadi totat harat temput adslah $85 \mathrm{~km}$}

Gambar 6. Jawaban Subjek DU tahap Evaluasi

Subjek S-DU terhadap soal juga dijelaskan kembali pada saat wawancara dengan peneliti. Subjek memberikan penjelasan tentang kegiatan dalam memeriksa kembali jawaban yang ditulisnya dan subjek meyakini hasil yang diperolehnya adalah jawaban yang benar padahal terdapat kesalahan pada pekerjaannya. Subjek S-DU adalah subjek dengan kemampuan kognitif impulsif berjenis kelamin perempuan. Pada instrumen pertama subjek S-DU melakukan kesalahan pada tahap pemantauan (monitoring) dan pengevaluasian (evaluation). Pada tahap pemantauan subjek tidak menyadari adanya kesalahan pada jawabannya dan pada tahap pemantauan subjek tidak melakukan penghapusan/penggantian jawaban yang salah serta tetap meyakini bahwa jawabannya tepat.

\section{Perbandingan aktivitas metakognitif mahasiswa perempuan impulsif dengan perempuan reflektif}

Terdapat beberapa perbedaan aktivitas metakognitif dari mahasiswa pemempuan dengan gaya impulsif dan reflektif. Perbedaan tersebut dapat dilihat pada tabel berikut. 
Tabel 3. Perbedaan Aktivitas Metakognitif Perempuan Impulsif dan Perempuan Reflektif

\begin{tabular}{|c|c|c|c|}
\hline $\begin{array}{c}\text { Aktivitas } \\
\text { Metakognitif }\end{array}$ & Perempuan Impulsif & Perempuan Reflektif & Perbedaan \\
\hline $\begin{array}{l}\text { Perencanaan } \\
\text { (planning) }\end{array}$ & $\begin{array}{l}\text { Menuliskan yang diketahui, } \\
\text { ditanya, menentukan tujuan, } \\
\text { memperoleh sesuatu yang } \\
\text { bermanfaat dari data, } \\
\text { menentukan hubungan } \\
\text { antara data dengan yang } \\
\text { ditanyakan, memperoleh } \\
\text { rencana, memperoleh } \\
\text { rencana penyelesaian soal } \\
\text { dan dapat menghubungkan } \\
\text { dengan suatu konsep. }\end{array}$ & $\begin{array}{l}\text { Menuliskan yang diketahui, } \\
\text { ditanya, menentukan tujuan, } \\
\text { memperoleh sesuatu yang } \\
\text { bermanfaat dari data, } \\
\text { menentukan hubungan antara } \\
\text { data dengan yang ditanyakan, } \\
\text { memperoleh rencana, } \\
\text { memperoleh rencana } \\
\text { penyelesaian soal dan dapat } \\
\text { menghubungkan dengan suatu } \\
\text { konsep. }\end{array}$ & $\begin{array}{l}\text { Tidak } \\
\text { perbedaan }\end{array}$ \\
\hline $\begin{array}{l}\text { Pemantauan } \\
\text { (monitoring) }\end{array}$ & $\begin{array}{l}\text { Meyakini penyelesaian yang } \\
\text { dipilihnya } \\
\text { menetapkan } \\
\text { benar, } \\
\text { hasil, } \\
\text { perhitungan tahap demi } \\
\text { tahap dan analisis } \\
\text { kesesuaian hasil dengan } \\
\text { pencapaian tujuan namun } \\
\text { belum mampu mengontrol } \\
\text { kemungkinan kesalahan. }\end{array}$ & $\begin{array}{l}\text { Meyakini penyelesaian yang } \\
\text { dipilihnya benar, melakukan } \\
\text { langkah yang mantap, dapat } \\
\text { mengingat informasi yang } \\
\text { penting, menetapkan hasil, } \\
\text { mengontrol kemungkinan } \\
\text { kesalahan pada langkah, } \\
\text { memeriksa kecermatan } \\
\text { perhitungan tahap demi tahap } \\
\text { dan analisis kesesuaian hasil } \\
\text { dengan pencapaian tujuan. }\end{array}$ & $\begin{array}{l}\text { Perempuan } \\
\text { impulsif tidak } \\
\text { menyadari } \\
\text { adanya } \\
\text { kesalahan. }\end{array}$ \\
\hline $\begin{array}{l}\text { Pengevaluasian } \\
\text { (evaluation) }\end{array}$ & $\begin{array}{l}\text { Meneliti } \\
\text { pekerjaannya, mengecek } \\
\text { kebenaran hasilnya, dan } \\
\text { meyakini bahwa evaluasi } \\
\text { sudah benar padahal masil } \\
\text { ada kesalahan. Tidak } \\
\text { mengenali adanya kesalahan } \\
\text { perhitungan dan penulisan } \\
\text { rumus, tidak melakukan } \\
\text { perbaikan kesalahan. }\end{array}$ & $\begin{array}{lr}\text { Meneliti } & \text { kembali } \\
\text { pekerjaannya, mengenali } \\
\text { kekurangan yang } \quad \text { sudah } \\
\text { dilakukan, mengecek } \\
\text { kebenaran hasilnya, mengenali } \\
\text { adanya kesalahan, melakukan } \\
\text { perbaikan kesalahan dan } \\
\text { meyakini diri bahwa } \\
\text { evaluasinya sudah benar. }\end{array}$ & $\begin{array}{l}\text { Perempuan } \\
\text { impulsif tidak } \\
\text { menyadari } \\
\text { adanya } \\
\text { kesalahan dan } \\
\text { tidak melakukan } \\
\text { perbaikan } \\
\text { kesalahan. }\end{array}$ \\
\hline
\end{tabular}

Berdasarkan tabel, mahasiswa perempuan dengan kemampuan kognitif reflektif melakukan aktivitas sesuai dengan indikator pada masing-masing aktivitas metakognitif. Sedangkan mahasiswa perempuan dengan kemampuan kognitif impulsif melakukan aktivitas sesuai dengan beberapa indikator pada beberapa aktivitas metakognitif. Hal ini menyebabkan mahasiswa perempuan dengan kemampuan kognitif reflektif yang secara konsisten mampu menjawab semua permasalahan yang diberikan dengan hasil akhir yang benar. Hal tersebut berbanding terbalik dengan mahasiswa perempuan dengan kemampuan kognitif impulsif yang secara konsisten belum mampu menjawab semua permasalahan yang diberikan dengan hasil akhir yang benar karena tidak menyadari adanya kesalahan dan tidak melakukan perbaikan kesalahan. Perbedaan aktifitas metakognitif ini sejalan dengan penelitian Lestari (2012), Widadah, Afifah, dan Pos (2013), dan Suwasti (2016) yang menemukan bahwa siswa bergaya kognitif impulsif belum melakukan semua aktivitas 
metakognisi yang meliputi mengembangkan perencanaan, memonitor pelaksanaan, dan mengevaluasi tindakan yang ditunjukkan dengan adanya indikator yang belum terpenuhi pada beberapa aktivitas metakognisi.

Mahasiswa perempuan kategori kognitif reflektif juga dapat secara konsisten menjawab semua permasalahan dengan hasil akhir yang benar. Hal ini karena mahasiswa dalam katagori ini dapat mengembangkan proses metakognisinya dengan baik sehingga dapat berhasil memecahkan masalah yang diberikan. Hasil tersebut sesuai dengan pendapat dari beberapa peneliti (Panaoura \& Philippou, 2005; Gama, 2004; Anderson, Betts, Ferris, \& Fincham, 2011) yang mengemukakan bahwa keberhasilan seseorang dalam menyelesaikan masalah turut dipengaruhi oleh aktivitas metakognisinya. Hasil berbeda ditunjukkan oleh mahasiswa perempuan dengan gaya kognitif impulsif yang menunjukkan bahwa mahasiswa pada kategori ini memiliki permasalahan dalam mengembangkan aktivitas metakognisinya ketika memecahkan masalah sehingga beberapa indikator kemampuan metakognisi yang diharapkan muncul belum dapat dicapai dengan baik.

Implikasi hasil penelitian ini dalam pembelajaran adalah kita dapat mengetahui perbedaan kemampuan metakognisi yang dimiliki setiap mahasiswa sehingga perlakuan dalam proses pembelajaran dapat disesuaikan dengan kemampuan metakognisi mereka, karena hasil penelitian menunjukkan bahwa mahasiswa dengan gaya kognitif reflektif dan impulsif memiliki cara yang berbeda dalam menyadari proses berpikirnya (metakognitifnya) ketika dihadapkan pada permasalahan matematika.

\section{SIMPULAN}

Berdasarkan deskripsi dan analisis hasil penelitian yang telah dilakukan dapat disimpulkan sebagai berikut:

1. Aktivitas metakognitif mahasiswa matematika Universitas PGRI Semarang berjenis kelamin perempuan dengan gaya kognitif impulsif dalam pemecahan masalah bangun datar yaitu belum mampu menyadari proses berpikirnya dengan baik, menyebabkan mahasiswa dengan gaya kognitif impulsif yang secara konsisten dengan waktu yang singkat belum mampu menjawab semua permasalahan yang diberikan dengan hasil akhir yang benar.

2. Aktivitas metakognitif mahasiswa matematika Universitas PGRI Semarang berjenis kelamin perempuan dengan gaya kognitif reflektif dalam pemecahan masalah bangun datar yaitu mampu menyadari proses berpikirnya dengan baik pada tahap perencanaan, memonitoring dan mengevaluasi. Hal ini menyebabkan subjek dengan gaya kognitif reflektif yang secara konsisten mampu menjawab semua permasalahan yang diberikan dengan hasil akhir yang benar meskipun dengan waktu yang lama.

\section{DAFTAR RUJUKAN}

Anderson, J. R., Betts, S., Ferris, J. L., \& Fincham, J. M. (2011). Cognitive and metacognitive activity in mathematical problem solving: prefrontal and parietal patterns. Cognitive, Affective, \& Behavioral Neuroscience, 11(1), 5267.

Begerson, T. (2000). Teaching and Learning Mathematics: Using Research to Shift from the "Yesterday" Mind to the "Tomorrow" Mind. Washington: superintendent of Public Instruction. 
De Corte, E. (2003, September). Intervention research: A tool for bridging the theory-practice gap in mathematics education.

In Proceedings of the International Conference, The Mathematics Education into the 21st Century Project, Brno Czech Republic.

Flavell, J. H. (1979). Metacognition and cognitive monitoring: A new area of cognitive-developmental inquiry. American psychologist, 34(10), 906.

Gama, C. (2004). Towards a model of metacognition instruction in interactive learning environments. Teste de Doutorado, University of Sussex, Inglaterra.

Istarini, Ferny S. (2010). "Metakognisi Mahasiswa Dalam Memecahkan Masalah Matematika Berdasarkan Tingkat Kemampuan Matematika Mahasiswa Kelas VIII SMP Negeri I Sukodono". Skripsi tidak diterbitkan. Surabaya: Jurusan Matematika Fakultas Matematika dan Ilmu Pengetahuan Alam Unesa.

Kirkley, J. (2003). Principles of teaching problem solving: technical paper 4 . Plato Learning Inc.

Lestari, Y. D. (2012). Metakognisi Siswa dalam Memecahkan Masalah Matematika Berdasarkan Gaya Kognitif. MATHEdunesa, 1(1). http://jurnalmahasiswa.unesa.ac.id/ar ticle/400/30/article.pdf

Livingstone, J. A. (1997). Metacognition: An Overview, http://www.gse.buffalo.edu/fos/shuel /cep564/metacog.html

Muhtarom, Suyono, W., \& Sugiyanti. (2013). Analisis Kesalahan Mahasiswa Pendidikan Matematika dalam Pemecahan Masalah Bangun Datar. Laporan Penelitian IKIP PGRI Semarang.
Panaoura, A., \& Philippou, G. (2004). Young Pupils' Metacognitive Abilities in Mathematics in Relation to Working Memory and Processing Efficiency. In Proceedings of the International Biennial SELF Research Conference. https://pdfs.semanticscholar.org/f046 /cd709526a7d5333a2505af8a61fa27c 58e14.pdf

Panaoura, A., \& Philippou, G. (2005). The measurement of young pupils' metacognitive ability in mathematics: The case of self-representation and self-evaluation. In Proceedings of CERME(Vol. 4). 255-264.

Polya, G. (1973). How To Solve It. Second Edition. Princeton University Press. Princeton: New Jersey.

Suwasti, P. (2016). Aktivitas Metakognisi Siswa SMA dalam Memecahkan Masalah Program Linear Ditinjau dari Gaya Kognitif Reflektif-Impulsif dan Jenis Kelamin (Doctoral dissertation, Universitas Sebelas Maret).

Widadah, S., Afifah, D. S. N., \& Pos, J. J. K. (2013). Profil Metakognisi Siswa Dalam Menyelesaikan Soal Sistem Persamaan Linear Dua Variabel Berdasarkan Gaya Kognitif. Jurnal Pendidikan Matematika, 13-24.

Warli. (2010). Profil kreativitas mahasiswa yang bergaya kognitif reflektif dan mahasiswa yang bergaya impulsif dalam memecahkan masalah geometri. Disertasi tidak diterbitkan. Surabaya: Program Pasca sarjana Unesa.

Wong, P. (1992). Metacognition in Mathematical Problem Solving. Singapore Journal of Education, 12(2), 48-58. 